\title{
The Regulations of Corporate Action in Capital Market in Indonesia
}

\author{
Dwi Elok Indriastuty Sekaring Ayumeida Kusnadi Farina Gandryani \\ Rahmadi Mulyo Widiyanto Chamdani \\ Faculty of Law, Wijaya Putra University
}

\begin{abstract}
Disclosure principles is the main principle in capital market which must be obeyed by issuers since the general offering until the company became public company, should do corporate action. The regulation of corporate action procedure in capital market is fundamentally an effort of law protection for the minority shareholders and independent shareholders. There is a collision between the regulation of company act and capital market act in the practice. This condition, by law, can be called as conflict of norm, as there is conflict between the statute. In facing the problem, principle of justice can be applied to legitimize and have normative influence. Principle of justice that underlies the application of preference to the two laws and regulations is lex specialis derogat legi generali principle. This principle is a method of resolving conflict of norm between specific norm and general norm. It means that the application of the preference principle is done by putting a side the norms or provisions, in this case is the company act by norms or specific provisions, which is the capital market act.
\end{abstract}

Keywords: Corporate Action, Capital Market, Conflict of Norm, Preference.

DOI: $10.7176 / \mathrm{JLPG} / 111-05$

Publication date:July $31^{\text {st }} 2021$

\section{Introduction}

The implementation of disclosure principles by issuers in capital market is not conducted only at the general offering but also must be obeyed after the company became public company. Disclosure principle is obliged when public companies do corporate action. Fundamentally, company activity that impacted to the alteration of capital structure and financial position can be categorized as corporate action. Beside that, in every corporate action will influence the cost and the published amount. This view is told by Francis Groven who stated that corporate action occurs when changes are made to the capital structure or financial position of an issuer of a security that affect any of the securities it has issued. ${ }^{1}$

As seen in the purpose of corporate action, it can be divided into some types:

1. Corporate action to distribute opulence, as in the distribution of dividend and bonus stock;

2. Corporate action to get new capital, as in the first stock offering, right issue and bond publishing;

3. Corporate action to reconstruct finance, as in capital alleviation and stock split;

4. Corporate action to reconstruct company, as in takeover, merger and consolidation. ${ }^{2}$

The emerging problem is the regulation in capital market act associated to the corporate action has special characteristic if it juxtaposed to the regulation in Law Number 40 of 2007 regarding Limited Liablity Company ("Company Act"). This case is seen after a company carries out initial public offering. Besides the status that will change into public company, as the consequency, the issuers are not only submissive to Company Act, but in some specific matters, they also obey the provisions in Law Number 8 of 1995 regarding Capital Market ("Capital Market Act"). Likewise, in associated to corporate action carries out by public company, other than complying with the provisions stipulated in the Company Act, they are also required to follow special requirements stipulated in Capital Market Act.

\section{Discussion}

\subsection{Regulations of Corporate Action in the Capital Market}

The procedural regulations concerned to corporate action in the capital market are basically to implement the principle of transparency and as an effort to provide legal protection for minority shareholders and independent shareholders. There are several provisions for corporate action, including the takeover of public company, mergers and consolidation of business.

\subsubsection{The Takeover of Public Company}

The terminology of the takeover of the company is regulated in Article 1 number 11 Company Act which determines "... A takeover is a legal act carries out by legal entity or individual to take over the shares of the company that cause the transfer of control on the company." The point in the provision of this article is that a

\footnotetext{
${ }^{1}$ Francis Groves, Corporate Actions-a Concise Guide: An Introduction to Securities Events, Harriman House Ltd, Great Britian, 2008 , p.4. ${ }^{2}$ Michael Simmons and Elaine Dalgleish, Corporate Actions: A Guide to Securities Event Management, Hoboken: Jhon Wiley \& Son, 2006, p.3, quoted from Mutiara Rengganis and Richele S. Suwita, The Regulation of Corporate Action in Capital Market by Financial Service Security, Law \& Capital Market Journal, Capital Market Law Consultant Association, Vol.VIII.ED.13/2017, p.49.
} 
legal action is done either by a legal entity or individual who takes over the shares of a company which resulted in the transfer of control over the company. The terminology of company takeover or acquisition in some literatures known as acquisition or take over is one company taking over controling interest in another company ${ }^{1}$ which implies the takeover for the importance of company controlling by another company.

The regulation of takeover is stipulated in Article 125 (1) of Company Act which determines: "A takeover is done by taking over shares that have been issued and/or will be issued by a company through the company's board of directors or directly from the shareholders." Furthermore, in the Article 125 (3) it is emphasized that: "The takeover as stated in paragraph (1) is the takeover of shares which causes the transfer of control of the company."

Basically, to protect the interests of public shareholders and as an effort to improve the quality of information disclosure of every transaction on the shares of a public company that has the potency to change the controlling shareholders in the public company, it must be done through tender offer. The regulation of tender offer is stipulated in Article 83 of Capital Market Act that stated: "Every party that makes a tender offer to purchase the issuers' Securities or public company obligated to follow the provisions of transparency, fairness and reporting that is stipulated by Capital Market Supervisory Agency." In the explanation of Article 83 of the Capital Market Act, it is explained: "What is meant by 'tender offer' in this article is the offer through mass media to obtain equity Securities by purchasing or exchanging with other Securities. What is meant by 'equity Securities' in the explanation of this article is the shares or securities that can be exchanged with other shares or securities containing the right to acquire shares."

The procedure of public company takeover regulated in the Regulation of Financial Servises Authority Number 9 /POJK.04/2018 on Public Company Takeover. The regulation background on tender offer is related to a transaction that has the potency to change the controlling shareholders in a public company. This case reminds that tender offer is an offer to purchase Security from public shareholders that resulted to the decreasing number of shareholders significantly and there is a possibility that related company is no longer qualifying as Public Company. For this reason, protection to public shareholders is needed. The effort to protect public shareholders is carried out to make sure that tender offer transaction is fair. The fairness, particularly in acquiring information about the proposed tender offers program, including cost pricing, Securities selling method, as well as specific requirements that can cancel the tender offer. The regulation about tender offer is the corporate action in the form of public company takeover that is used to protect the interests of public shareholders on the takeover by the new controller in a public company.

In taking over company in the capital market, the regulation is oriented on the process and method of the company takeover especially public company takeover. Both in taking over public company directly and inderctly that cause the change of controller in that public company. Public company controllers, are the direct and indirect parties:

a. Own more than $50 \%$ (fifty percent) of Public Company Shares from the whole shares with voting right that is fully paid-in; and/or

b. Have the ability to define, direct and indirect, with all methods of management and/or public company policies.

The takeover of public company that causes the cange of controlling in a company must do tender offer, that is an offer to purchase outstanding stock for new controllers. And every party that does tender offer to purchase Issuers' Securities or public company should follow the provision of transparency, fairness and reporting that is set by Financial Services Authority.

\subsubsection{Business Consolidation and Merger}

The understanding of business consolidation according to provision regulated in Article 1 (9) of Company Act is a legal act done by one corporation or more to merge with other corporation and caused the assets and liabilities of the merged corporation to devolve upon the corporation legally and the legal status of the merged corporation is ended by law. Bryan A Garner limited merger as follows:

"Merger is an amalgamation of two corporation pursuant to statutory provising in which one of the corporation survives and the other disappear. The absorption of one company by another, the former losing its legal identity and latter retaining its own name and identitu and acquiring assets, liabilities, franchise, and powers of former, and absorbed company ceasing exist as separate business entity". ${ }^{2}$

It is almost similar to takeover company, in business consolidation or merger is known some forms:

a. Merger Horisontal, when two companies with the same business line are merged or when the companies that compete in the same industry are merged;

b. Merger Vertical, inculpating different operational production stage that correlated one to another, from head to toes.

\footnotetext{
${ }^{1}$ Jack P., Friedman, Dictionary of Business Terms, New York, USA Barron's Educational Series Inc., 1987., p.10.

${ }^{2}$ Bryan A Garner, Op. Cit, Garner, Bryan A.. Black's Law Dictionary, Eleventh Edition, Thomson Reuters, St. Paul, Minn., 2019, p. 1184.
} 
c. Merger Conglomerate, when 2 (two) companies with different business lines are merged. In another word, merger conglomerate happens between companies that do not compete against each other and do not have seller - buyer relation. ${ }^{1}$

It is different from business consolidation, according to Article 1 (10) of Company Act, merger in literature mostly called as consolidation or in Dutch literature it is called "fusie", ${ }^{2}$ a legal act carries out by two or more corporations to merge by establishing one new corporation that legally obtains assets and liabilities of the merged corporations and the legal status has ended. An almost similar opinion stated that fusie or absorption happens through the consolidation of 2 (two) or more companies, where 1 (one) of them, the smaller company will lose its identity and merge or become the part of the other existing (surviving) company that keeps its name and identity. ${ }^{3}$

The regulation about consolidation and merger in capital market is regulated in Article 84 of Capital Market Act that stated “... Issuers or public company that carry out merger, consolidation or takeover another company should follow the provisions of transparency, fairness and reporting as stipulated by Capital Market Supervisory Agency and other applicable laws and regulations."

The explanation of Article 84 of Capital Market Act is more emphasized than the purpose of combination and merger which is more oriented on the protection of investors' interests and to comply with the principle of disclosure in capital market as explained below:

The provision referred to in this Article is intended to protect the interest of investors from harmful practices in merger, consolidation or takeover transactions, including participation involving Issuers or public companies, by requiring the issuers or public companies to comply with Principles of disclosure and reporting stipulated by Capital Market Supervisory Agency. The implication of this provision is carried out without diminishing the provisions of the Company Act.

Regulation relating to business mergers and consolidation procedures are regulated in Financial Services Authority Regulation Number 74/POJK.04/2016 concerning Business Mergers and Consolidation ("POJK 74/POJK.04/2016"). One of the main objectives of the regulation of POJK 74/POJK.04/2016, is to protect investors especially public shareholders, to maintain an orderly, fair, transparent and accountable capital market operation. In addition, the aim is also to provide convenience for public companies that will do business merger and consolidation with certain conditions and requirements as well as to improve the quality of information transparency in the business mergers and consolidation plan.

There is provision that requires public company before doing business mergers and consolidation, every board of directors is required to prepare a business mergers and consolidation plan as regulated in Article 3 of POJK 74/POJK.04/2016 as follows :

(1) The Board of Directors of each company that will carry out a business mergers or business consolidation mutually should prepare a plan for business mergers or ubsiness consolidation.

(2) Business mergers and consolidation plan as referred to in paragraph (1) must be approved by each company's board of commissioners.

The information that must be included in business mergers and consolidation plan, regulated in Article 4 Paragraph (1), POJK 74/POJK.04/2016, which stipulates as follows:

(1) Business mergers and consolidation plan as stated in Article 3 at least contains information:

a. Name, domicile, business activity, capital structure and shareholders, and management and supervision of each company that will do business mergers and consolidation;

b. Name and domicile of the company resulting from business mergers and consolidation;

c. The structure of the members of board of directors and members of board of commissioners of the company resulting from business mergers and consolidation;

d. Business mergers and consolidation schedule;

e. The reasons and explanations for conducting business mergers and consolidation from each company that will do business mergers and consolidation;

f. The procedure for stocks convertion of each company that will do business mergers and consolidation to the stocks of the company resulting from it;

g. The draft amendment to statutes of the company resulting from business mergers and consolidation (if any) or the draft of article incorporation of the new company resulting from business consolidation;

h. The recapitulation of important financial data sourced from financial report that has been audited by public accountant from each company that will do business mergers and consolidation, with the following conditions:

1. The companies that will do business mergers and consolidation are public company, for the last 2

\footnotetext{
${ }^{1}$ Andi Fahmi Lubis, Anna Maria Tri Anggraini, Kurnia Toha, Budi Kagramanto,et al, Business Competition Law, between Text and Context, Deutsche Gesellschaft fur Tehnische Zusammenarbeit, Indonesia, 2009, p.191

${ }^{2}$ Rudhi Prasetya, Limited Company, Theory and Practice, Sinar Grafika, Jakarta, 2011, p. 92-93.

${ }^{3}$ Andi Fahmi Lubis, Anna Maria Tri Anggraini, Kurnia Toha, Budi Kargramanto, et al., Ibid.
} 
(two) years; or

2. Companies that will do business mergers and consolidation are not public company, for the last 3 (three) years.

i. There is interim period financial data, presenting a comparison of the same interim period from the previous year (it doesn't need to be audited), except for the report of financial position;

j. Proforma financial information of the company resulting from business mergers and consolidation that has been audited by public accountant;

$\mathrm{k}$. The summary of the appraiser's report regarding the stocks assessment of each company that will do business mergers and consolidation covering at least:

1. Party's identity;

2. Assessment object;

3. Assessment Purpose;

4. Assumptions and divider conditions;

5. Assessment approach and method; and

6. Assessment result;

1. The summary of Appraiser's report regarding the fairness opinion on the business mergers and consolidation;

$\mathrm{m}$. The result of the expert's assessment regarding certain aspect from business mergers and consolidation (if necessary);

$\mathrm{n}$. The opinion of the legal consultant regarding legal aspects of business mergers and consolidation;

o. The settlement method of employees' status of the company that will do business mergers and consolidation;

p. The settlement method of the rights and obligations of the company that will do business mergers and consolidation to the third party;

q. The settlement method of the rights of the shareholders who oppose the Business business mergers and consolidation; and

r. The explanation of the benefits, risks that may rise because of business mergers and consolidation, and future business plan.

The information that should be written in business mergers or consolidation plan as stipulated in Article 4, POJK 74/POJK.04/2016 is more comprehensive compared to the formulated program as regulated in Article 123 of Company Act. This case is possible because in paragraph (5) Article 123 of Company Act provides flexibility in the Capital Market Act and the regulation implementer to determine and/or regulate other as formulated "... The provisions regarding merger and consolidation plan are also applied to public company as long as it is not regulated in law and regulation in capital market sector."

In the provision POJK 74/POJK.04/2016, shows special attention that may rise because of business mergers and consolidation on public company. This case does not provide protection to the investor or the minority shareholders. In the provision in POJK 74/POJK.04/2016, requires the statements in business takeover and merger plan regarding the candidate of public company controller as stipulated in Article 7 as follows:

In the case of business mergers and consolidation will result to a new controller in the public company, business mergers or consolidation plan is also obligated to contain:

a. Explanation regarding the controller candidates of a public company, at least covering:

1. The candidates of public company controller are individual, the information of name, address and the affiliated relation with the public company (if available); or

2. The candidates of public company controller are other parties besides individual, the information that must be reavealed are:

a). Name;

b). Domicile or the address of the headquarter;

c). Business sector;

d). Legal status;

e). Management and suprvisor structure;

f). Capital structure or equivalent information;

g). Financial data recapitulation;

h). Beneficiary of the controlling candidate; and

i). Characteristic of affiliated relation to the public company.

\subsection{Capital Market Act Preference}

According to the explanation on the previous chapter, shows that corporate action in capital market is a common thing either in developing company or in the restructuring organization framework. The provisions related to corporate action that applied in capital market, despite oriented to business development, the implementation 
procedures compulsory watch the interest of investors, minority shareholders and independent shareholders. It describes the problem where there is collision between the regulations in Company Act and Capital Market Act. This condition in legal practice is called conflict of norm, a condition where there is conflict between the content of one statute to another statute. In this condition, the function of legal principles can legitimize and have normative influence and bind the parties. ${ }^{1}$

In the legal order which consists of principles, norms and regulations of law arranges the life of legal subject in the society, and the whole organisations and processes needed to create law in real life. Legal order elements are organized hierarchically in a legal law system due to the work of legal principles.

These legal principles that express logical function of humans' common sense, actually the inherent in law and in the understanding and in the existence of legal order itself that is brought by the reality and legal purpose are stability, predictability in order to create assurance and justice. ${ }^{2}$

Basically, asas' is also called principles, so the understanding of asas hukum is similar to the legal principles. ${ }^{3}$ Legal principles is a thing than can be the focus of thinking and opinion. Asas originated from Arabic which means the outset of building, the base or foundation. ${ }^{4}$ While the principle means taking or putting something as the first thing, the beginning, the base, basis or foundation. ${ }^{5}$ Black Law Dictionary defines it as " $a$ basic rule, law, or doctrine. ${ }^{6}$

Paul Scholten defines legal principles as "basis thought, which is found inside and behind every legal system that has been formulated in laws and regulations and adjudication, that relates to the provisions and individual decisions can be seen as the explanation". ${ }^{7}$ Based on this definition, it is clear that the role of legal principles is as metanorm relating to legal norm in the form of behavioral norm. In other words, legal principles is metanorm or the values that base the legal norm.

The same view is stated by Ron Jue who explains legal principles as follows: "The values that base the meaning of legal norms is called legal principles. The principles define and legitimize legal norms. In consequence, legal norms that can be viewed as operationalization or processing furtherly from legal principles." 8

Legal principles (rechsbeginselen) is the base to form positive law. Djuhaendah Hasan describes the function of legal principles is to guide legislators in the process of law making. ${ }^{9}$ Legal principles is also functioned to give direction and guidance for the application of the rule into an apropriate form and composition for users of the right forming methods and to follow specified process and procedure as well as to be used to test (toetsen) whether the legal norms in law and regulations is correspond to the principles that have been used as the base of formation. ${ }^{10}$

Based on some definitions related to basis and principles, Budiono appraised that there are two concepts to be combined which are the truth in thinking and acting. The link is in the concept of "basis," that is every thinking or acting activity must be based on the truth. Truth is not the only basis or principle. To make the truth becomes basis or principle, it must be used as the base of thinking and other deeds. ${ }^{11}$

The principle that underlies the application of priority to the two laws and regulations is the principle of lex specialis derogat legi generali. This principle is one of the principle of preference known as legal principle that can be used in statutory approach. Basically, the use of lex specialis derogat legi generali principle refers to the two laws and regulations which hierarchically have the same position, but the scope of the material content among the two laws and regulations is more specific than the others. ${ }^{12}$

The principle of preference can be applied if one of them referred to the two laws and regulations of the same order and concerned for the same matter but one of them is more specific and another is general, Papinianus stated lex specialis derogat legi generali adage. ${ }^{13}$ This principle means that in an lawsuit or legal case

\footnotetext{
${ }^{1}$ Zainal Asikin, The Study of Law, Raja Grafindo, Jakarta, 2015, pg.100-112.

${ }^{2}$ Bernard Arief Sidharta, The Discovery of Law in the Study of Law Philosophy, in Law Antinomy Pendulum, Anthology of 70 Years Valerine J. L. Kriekhoff, Print out 1, Genta Publishing, Yogyakarta, 2014, pg.24.

${ }^{3}$ Peter Mahmud Marzuki, Law Theory, Kencana, Jakarta, 2020, pg. 18.

${ }^{4}$ Lalu Wira, Pria S, Legal Principles of General Mining, Dissertation, Postgraduate Program Airlangga University, 2008, pg. 8.

${ }^{5}$ Laica M Marzuki, Siri': A Part of Law Society Awareness Bugis-Makasar (A Law Philosophy Research) Hasanuddin University Press, Ujung Pandang, 1995, pg. 144.

${ }^{6}$ Bryan A Garner, Op.Cit, pg. 1444

${ }^{7}$ JJ.H. Bruggink, Reflection of Law, Basic Understanding of Law Theory. Translated, B. Arief Sidharta, Citra Aditya Bakti, print out IV, 2015, pg.119-120.

${ }^{8}$ R.J. Jue, Grondbeginselen van het Recht, 1990:63, quoted from Bruggink, Ibid, pg. 212.

${ }^{9}$ Djuhaendah Hasan, Legal System, Legal Principles and Legal Norms in Constructing National Law, in the reflection of Legal Dynamic, A Chain of Thought in the Last Decade, Public Company Printing of Republic Indonesia, 2008, pg.80.

${ }^{10}$ Hamid. S.A. Attamimi, The Role of Indonesia Presidential Decree in the Implementation of State Government Administration, Dissertation, Indonesia University, Jakarta, 1990, p.313.

${ }^{11}$ Rachman, A. Budiono, Legal Protection for Child Labor, Disertation, Airlangga University, Surabaya, 2007, p.36.

${ }^{12}$ Peter Mahmud Marzuki, Introduction of Law Study, Revised Edition, Print out $4^{\text {th }}$, Kencana Prenada Media Group, Jakarta, 2008 , p.139.

${ }^{13}$ P. van Dijk, et al, Van Apeldoorn's inleading tot de Studie va het Nederlandse Recht, W.E.J. Tjeenk-Willijnk, 1985. Quoted from Peter Mahmud Marzuki, Introduction of Law Study, Revised Edition, Print out 4 ${ }^{\text {th }}$, Kencana Prenada Media Group, Jakarta, 2008 , p. 260.
} 
there are two statutes that can be applied, so the statute that should be applied is the statute that specifically regulates the case. ${ }^{1}$

The principle of lex specialis derogat legi generali, is a settlement method of conflict of norms between specific norm and general norm. The use of this preference is carried out by setting aside (not to defeat) the general norm. However, the use of this principle is not to eliminate the specific norm, but only to prioritize it. ${ }^{2}$

This matter is getting clearer because it is explicitly written in Article 154 Paragraph (1) of Company Act which says: "As for Public Company, the provisions of this law shall apply if it is not regulated otherwise in the laws and regulations of Capital Market sector." However, not all laws and regulations stated their positions as in the provision of Article 154 paragraph (1) of Company Act as lex generalis. By observing the scope of material content of the two laws and regulations which hierarcichally similar, the lex specialis derogat legi generali prionciple can be used to support an argument for the preference of a particular laws and regulations. Moreover, in the explanation, Article 154 (1) of Company Act expounds that basically for corporation that carries out an activity in capital market sector, for example a public company or stock exchange applies in the provisions in the Company Act. However, considering the company's activity which has certain characteristic differs from the common corporation, it is necessary to open the possibility of specific regulations to the corporation.

\section{Conclusions}

Regulations in the Capital Market Act have different characteristics when compare to the regulations in Company Act. It corresponds to the characteristics of activity in capital market which oriented in providing legal protection for investors, minority shareholders and independent shareholders. The different characteristics are clearly seen in the provisions in associated to the corporate action in capital market differ from the same regulations in Company Act.

This condition in legal practice can be called as conflict of norm, where there is a conflict between the content of one statute and another statute. In facing this kind of matter, the function of basis or legal principles can be use to legalize and have normative influence. Legal principle that underlies the implication of preference for two laws and regulations is the principle of lex specialis derogat legi generali. The principle is a settlement method of conflict of norm between specific norm and general norm. It will not eliminate the general norm, but only to prioritize the specific norm. It means, if conflict of norm found in the practise, the provisions in capital market which are specific norms can set aside the provisions written in Company Act.

\section{References}

Asikin, Zainal, 2015, The Study of Law, Raja Grafindo, Jakarta.

Attamimi, Hamid. S.A., 1990, The Role of Indonesia Presidential Decree in the Implementation of State Government Administration, Dissertation, Indonesia University, Jakarta.

Bruggink, JJ.H., 2015, Reflection of Law, Basic Understanding of Law Theory. Translated, B. Arief Sidharta, Citra Aditya Bakti, Print Out IV, Bandung.

Budiono, Rachman, A., 2007, Legal Protection for Child Labor, Disertation, Airlangga University, Surabaya.

Dijk, P. van et al, 1985, Van Apeldoorn's inleading tot de Studie va het Nederlandse Recht, W.E.J. TjeenkWillijnk.

Friedman, Jack P.,1987, Dictionary of Business Terms, New York, USA Barron's Educational Series Inc.

Garner, Bryan A. 1999, Black's Law Dictionary, Seventh Edition, West Group, St. Paul, Minn.

Groves, Francis, 2008, Corporate Actions-a Concise Guide: An Introduction to Securities Events, Harriman House Ltd, Great Britian.

Hasan, Djuhaendah, 2008, Legal System, Legal Principles and Legal Norms in Constructing National Law, in the reflection of Legal Dynamic, A Chain of Thought in the Last Decade, Public Company Printing of Republic Indonesia.

Jue, R.J., 1990, Grondbeginselen van het Recht.

Laica M Marzuki, 1995, Siri': A Part of Law Society Awareness Bugis-Makasar (A Law Philosophy Research), Hasanuddin University Press, Ujung Pandang.

Lubis, Andi Fahmi, Anna Maria Tri Anggraini, Kurnia Toha, Budi Kagramanto,et al, 2009, Business Competition Law, between Text and Context, Deutsche Gesellschaft fur Tehnische Zusammenarbeit, Indonesia.

Mangesti, Yovita Arie Slamet Suhartono, 2020, The Study of Law Contemporer, Breaking Through the Rigidity Limit of Normative Law, Setara Press, Malang.

Marzuki, Peter Mahmud, 2008, Introduction to Law Study, Revised Edition, Print out $4^{\text {th }}$, Kencana Prenada Media Group, Jakarta.

\footnotetext{
${ }^{1}$ Peter Mahmud Marzuki, Ibid.

${ }^{2}$ Yovita Arie Mangesti, Slamet Suhartono, the Study of Law Contemporer, Breaking Through the Rigidity Limit of Normative Law, Setara Press, Malang, 2020, P.78.
} 
Marzuki, Peter Mahmud, 2005, The Research of Law, Kencana Prenada Media Group, Jakarta.

Marzuki, Peter Mahmud, 2020, Law Theory, Kencana, Jakarta.

Prasetya, Rudhi, 2011, Limited Company, Theory and Practice, Sinar Grafika, Jakarta.

Pria S, Lalu Wira, 2008, Legal Principles of General Mining, Dissertation, Postgraduate Program of Airlangga University.

Rengganis, Mutiara and Richele S. Suwita, 2017, The Regulation of Corporate Action in Capital Market by Financial Service Security, Law \& Capital Market Journal, Capital Market Law Consultant Association, Vol.VIII.ED.13/2017.

Sidharta, Bernard Arief, 2014, The Discovery of Law in the Study of Law Philosophy, in Law Antinomy Pendulum, Anthology of 70 Years Valerine J.L. Kriekhoff, Print out 1, Genta Publishing, Yogyakarta.

Simmons, Michael and Elaine Dalgleish, 2006, Corporate Actions: A Guide to Securities Event Management, Hoboken: Jhon Wiley \& Son. 